\title{
Metastasizing Maxillary Ameloblastoma: Report of a Case with Molecular Characterization
}

\author{
Matteo Rotellini', Giandomenico Maggiore ${ }^{2}$, Massimo Trovati², Massimo Squadrelli Saraceno², \\ Alessandro Franchi ${ }^{1}$
}

${ }^{1}$ Department of Surgery and Translational Medicine, Section of Anatomic Pathology, University of Florence, Italy.

${ }^{2}$ Second Otolaryngology Head and Neck Surgery Clinic, Azienda Ospedaliera Universitaria Careggi, Florence, Italy.

\author{
Corresponding Author: \\ Alessandro Franchi \\ Department of Surgery and Translational Medicine \\ University of Florence \\ Largo Brambilla 3, 50134, Firenze \\ Italy \\ Phone: +39055 4478102 \\ Fax: +39055 4379868 \\ E-mail: franchi@unifi.it
}

\begin{abstract}
Background: Ameloblastoma is a benign odontogenic tumour that may exhibit aggressive biological behaviour with local recurrence and metastasis following initial surgical resection. Surgery is the most acceptable modality of treatment, even if a biological approach is currently on study. We report a case of maxillary ameloblastoma with development of neck and brain metastases after repeated local recurrences. Molecular analysis was performed with the aim to better characterize this neoplasm and its peculiar behaviour.

Methods: We investigated the status of tumour protein p53 (TP53), epidermal growth factor receptor (EGFR), B-Raf protooncogene (BRAF) and human epidermal growth factor receptor 2 (HER2) genes with immunohistochemical, fluorescent in situ hybridization and/or direct sequencing in order to clarify their possible role in the development of this neoplasm and the possibility of a targeted treatment.

Results: The histological appearance of the tumour was the same in the primary lesion, in the recurrence and in the metastases. EGFR positivity was present in the recurrence and the brain metastasis, while HER2 was negative in all samples tested. Fluorescent in situ hybridization analysis for EGFR showed disomy of neoplastic cells. Direct DNA sequencing of TP53 gene exons 5 - 9 was carried out in tumour samples from the infratemporal recurrence and brain metastasis, with no mutational alteration detected. Similarly, sequencing analysis of BRAF exon 15 (V600) and EGFR gene showed wild type results in all samples tested.

Conclusions: Further studies are needed to identify molecular pathways that may provide an opportunity of alternative treatments and/or new potential predictive markers of local and distant spread of this rare tumour.
\end{abstract}

Keywords: ameloblastoma; human EGFR protein; human HER2 protein; metastasis; tumor suppressor protein p53.

\author{
Accepted for publication: 29 March 2016 \\ To cite this article: \\ Rotellini M, Maggiore G, Trovati M, Saraceno MS, Franchi A. \\ Metastasizing Maxillary Ameloblastoma: Report of a Case with Molecular Characterization \\ J Oral Maxillofac Res 2016;7(1):e5 \\ URL: http://www.ejomr.org/JOMR/archives/2016/1/e5/v7n1e5.pdf \\ doi: $10.5037 /$ jomr.2016.7105
}




\section{INTRODUCTION}

Ameloblastoma is a rare tumour of odontogenic epithelial origin, which accounts for approximately $1 \%$ of all mandibular tumours and cysts [1-2]. It has high propensity for local recurrence if not adequately removed and although the tumour may appear microscopically benign, the development of distant metastasis is possible. Classification as a benign or malignant lesion has generated much debate because ameloblastoma has different histopathologic patterns and displays a wide spectrum of biologic behaviours. In the WHO classification, a clear distinction between ameloblastoma, metastasizing ameloblastoma and ameloblastic carcinoma was made. Here, metastasizing ameloblastoma is defined as an ameloblastoma that metastasize in spite of a benign histology [3]. This occurrence is estimated in approximately $2 \%$ of the cases [4], and the most common site for metastasis is the lung $(75-80 \%)$ [ $]$ ], followed by the cervical lymph nodes, the diaphragm, the liver and the brain. On the other hand, ameloblastic carcinoma shows combined histologic features of ameloblastoma with cytologic atypia, regardless of the presence of metastasis [6]. This report describes a patient who presented a long history of local recurrence and distant metastasis of ameloblastoma. Molecular analysis was performed with the aim to better characterize this neoplasm and its peculiar behaviour.

\section{CASE DESCRIPTION AND RESULTS}

A 29-year-old male presented a swelling of the oral cavity without any symptoms. The radiographic examination showed diffuse opacity of the right nasal fossa and maxillary sinus, with destruction of the medial and inferior walls of the maxillary sinus, and thinning of the pavement of the orbita (Figure 1A). He underwent extended right maxillectomy with resection of a portion of the hard palate with a histologic diagnosis of ameloblastoma. In the following years, his medical history was significant for an adenocarcinoma of the colon and an acute myocardial infarction. After a disease-free interval of 20 years, the tumour recurred locally in the right maxillary sinus (Figure 1B), and the diagnosis of ameloblastoma was confirmed histologically. One year later a computed tomography highlighted a recurrence involving the right orbita (Figure 1C) and the hard palate (Figure 1D). The patient underwent hemifacial resection with orbital exenteration. After 10 months, twentyseven years after the onset of the primary lesion, the patient referred frontal headache, postural instability, disorientation and bewilderment with impaired shortterm memory. magnetic resonance imaging revealed a recurrence in the infratemporal fossa (Figure 1E) and a single metastasis in the right temporal area of the brain (Figure 1F). These were surgically removed, and the sphenoidal-orbital region and the right temporal lobe were also treated with radiation therapy (60 Gray total dose). Nine months later the patient developed a further metastatic deposit in the right neck, which was surgically removed. The patient is currently alive with disease localized in the brain.

\section{Histopathology}

The histological appearance of the tumour was the same in the primary lesion, in the recurrence and in the metastases. The tumour mainly presented a plexiform pattern, characterized by a proliferation of basal cells organized in anastomosing strands with an inconspicuous stellate reticulum (Figure 2). The basal cells were columnar and hyperchromatic, with nuclei displaced away from the basement membrane. In the primary lesion, focal areas of the tumour displayed cystic changes (Figure 2). There were no cytologic atypia, mitotic activity and areas of necrosis in any of the specimens.

\section{Immunohistochemistry}

The results of the immunohistochemical stainings are illustrated in Figure 3. Staining for epidermal growth factor receptor (EGFR) conducted on the infratemporal recurrence and on the brain metastasis, showed strong membrane and cytoplasmic positivity of neoplastic cells. Tumour protein p53 (TP53) nuclear immunostaining was detected in the majority of neoplastic cells. Conversely, human epidermal growth factor receptor 2 (HER2) was negative in all samples tested.

\section{Fluorescent in situ hybridization (FISH) analysis}

The analysis was conducted on the infratemporal recurrence. Neoplastic cells showed disomy, with an average ratio of EGFR gene to chromosome 7 centromere signals (CEP7) signals per cell of 0.8.

\section{Molecular studies}

Direct DNA sequencing of TP53 gene exons 5 - 9 was carried out in tumour samples from the infratemporal recurrence and brain metastasis, with no mutational alteration detected. Similarly, sequencing analysis of B-Raf proto-oncogene (BRAF) exon 15 (V600) and EGFR showed wild type results in all samples tested. 


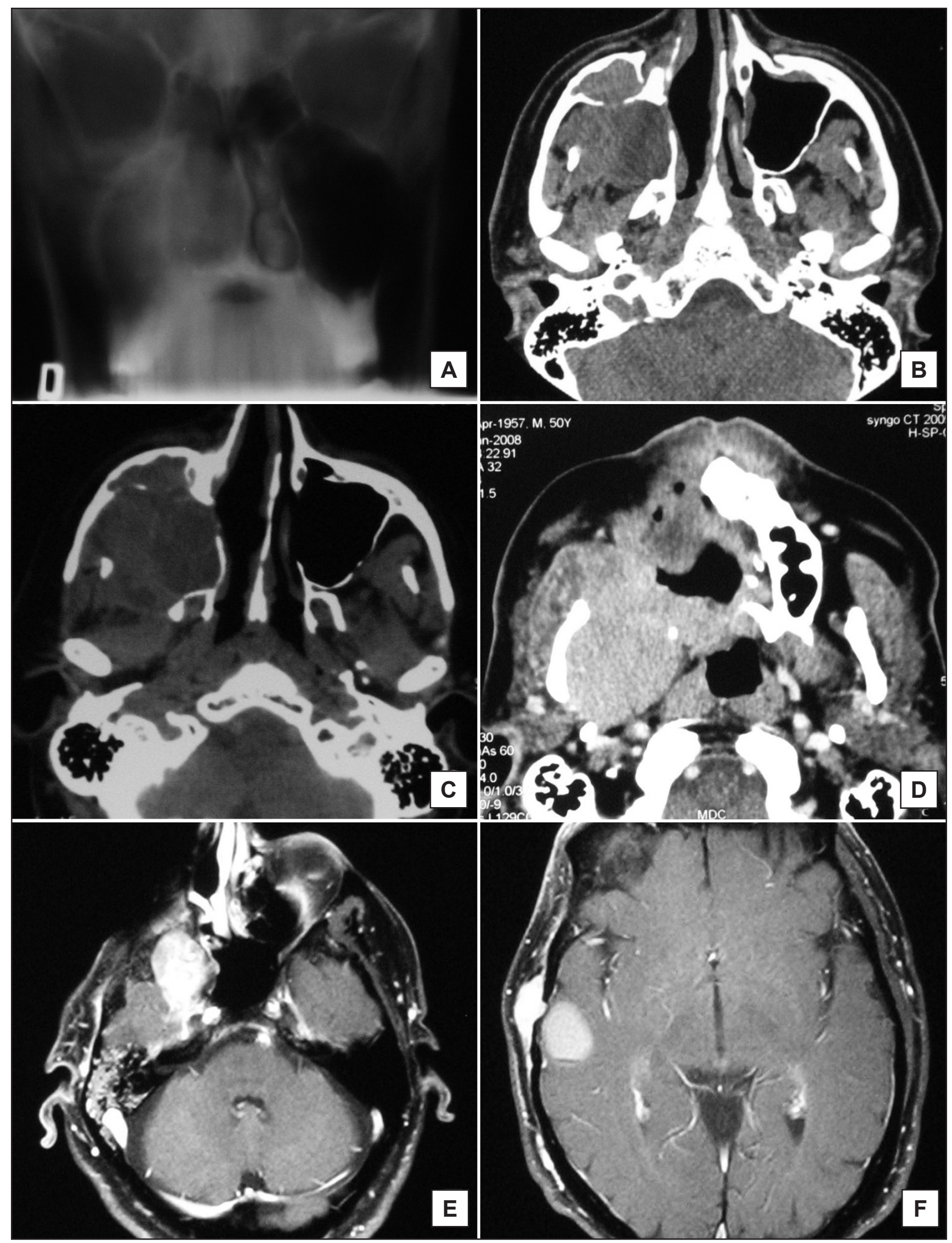

Figure 1. Radiographic appearance of the primary lesion. $\mathrm{A}=$ diffuse opacity of the right nasal fossa and maxillary sinus, with destruction of the medial and inferior walls of the maxillary sinus, and thinning of the pavement of the orbita. $\mathrm{B}=$ axial computed tomography showing the first recurrence in the maxillary sinus, which occurred 20 years after the surgical treatment of the tumour. $\mathrm{C}=$ after conservative treatment the tumour recurred in the right orbit. $\mathrm{D}=$ tumour recurred in hard palate. $\mathrm{E}=$ magnetic resonance imaging showing a recurrence in the infratemporal fossa. $\mathrm{F}=$ single metastasis in the right temporal area of the brain. 




Figure 2. $\mathrm{A}=$ low power view of the primary lesion, showing a plexiform pattern, with cystic areas. $\mathrm{B}=$ high power view of the primary lesion, showing anastomosing strands of epithelium in fibrous stroma, with tall columnar at the periphery. $\mathrm{C}=$ metastatic lesion of the neck, showing infiltration of the salivary tissue of the parotid gland. $\mathrm{D}=$ representative image of the brain metastasis.

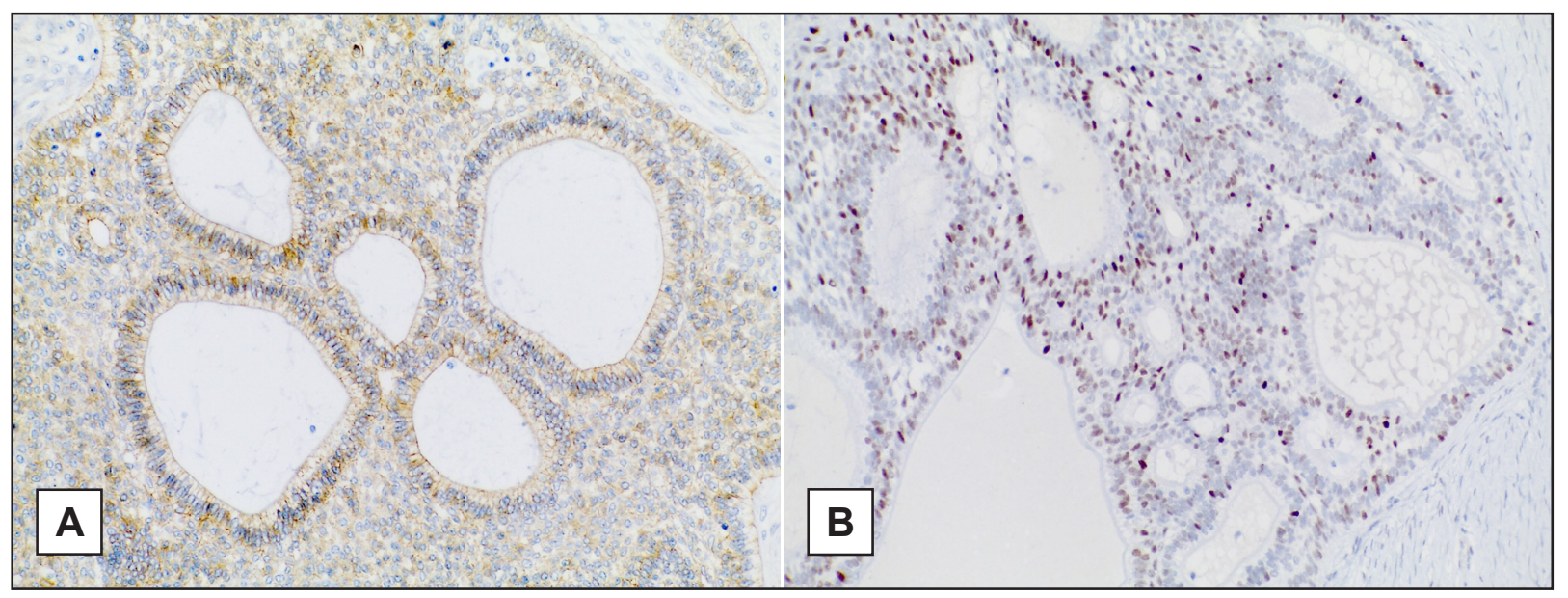

Figure 3. $A=$ Immunohistochemical staining showing positivity for EGFR. B = p53 in the neoplastic epithelium.

\section{DISCUSSION}

According to the current WHO classification, metastasizingameloblastoma shows the same histological features of non-metastasizing ameloblastoma, and therefore the diagnosis can be made only retrospectively, when metastasis has occurred [5]. Thus, it is difficult to predict the behaviour of this neoplasm, which has always an uncertain malignant potential. Generally accepted risk factors for the development of metastasis include large primary lesion, late diagnosis of the initial tumour, multiple local recurrences, inadequate surgical treatment, radio-chemotherapy treatment and plexiform pattern [7], even if the exact nature 
and the role played by each factor is not clear [8]. In addition, long-term follow-up is recommended [2], because metastasis may occur after a very long disease-free interval, which may be up to 42 years after the treatment of the primary lesion [7], with an average time to metastasis of 18 years [9]. Indeed, in the present case the first recurrence occurred 20 years after the primary lesion, and 7 years later two metastases were detected. However, according to Van Dam et al. [9], in the absence of malignant cytologic transformation of the metastatic lesion, the clinical course of the metastatic tumour is relatively indolent, with an average survival of 10 years after the diagnosis of metastasis.

In the recent past, several studies attempted to elucidate the complex aspects of ameloblastoma biology, in order to improve treatment and outcome of the patients. Currently, radical surgery is the elective therapy both for primary and secondary lesions. In addition, patients must be followed strictly with instrumental exams and punctual follow-up to prevent recurrence [1]. Radiotherapy and chemotherapy are reserved for the palliative setting and inoperable tumours [10].

Recently, several molecular studies have been undertaken in order to improve our understanding of the pathogenesis of this neoplasm, and to identify possible targets for alternative treatments, to potentially reduce the need for extensive and repeated surgery. The status of different genes has been evaluated, including transmembrane tyrosine kinase EGFR, BRAF, HER2 and TP53.

Epidermal growth factor and EGFR participate in the differentiation of ameloblasts and in the control of their cellular function [11]. EGFR regulates the proliferation of both normal and neoplastic cells, it is expressed by normal odontogenic epithelium and the presence of alterations of this gene has been investigated both with immunohistochemical [11-13] and molecular analysis [14].

Immunohistochemical studies have shown positivity for EGFR both in primary lesions and in metastases, although this marker did not predict recurrence [15]. In agreement, in the present case we observed EGFR cytoplasmic and membranous immunostaining in both the recurrence and the brain metastasis. In the molecular study performed by Kurppa et al. [14], an over-expression of EGFR was observed in ameloblastomas studied with real-time reverse transcription polymerase chain reaction (RT-PCR), while in the present case, FISH analysis did not demonstrate gene amplification. Moreover, gene sequencing did not identify any activating mutation of the EGFR gene. Therefore, data from literature indicate that anti-EGFR targeted therapy could be potentially used in the treatment of recurrent disease, especially in cases where the surgical approach is limited [15]. Indeed, as reported by Vered et al. [11], EGFR treatment is recommended in aggressive ameloblastomas not only in monotherapy, but also in combination with conventional radiotherapy. The administration of anti-EGFR agents could be also intralesional, to avoid the adverse events of the treatment. Recently, new anti-EGFR monoclonal antibodies were developed, and the target therapy with these drugs showed clinically successful results, underlying the possibility to control the disease also in advanced cases [11].

BRAF is a potent activator of the mitogen activated protein kinase (MAPK) cascade, which in turn phosphorylate and activate extracellular signalregulated kinases 1 and 2 (ERK1/ERK2) [16,17]. ERK regulates the expression of several genes through the phosphorylation of nuclear transcription factors or by targeting other intracellular signalling molecules. Thus, through the stimulation of ERK signalling, BRAF is capable to induce proliferation and to promote transformation. More than 40 different mutations are identified in BRAF gene human cancer [18]. Ninety percent of BRAF mutations are represented by a missense mutation at residue 600 that substitutes a glutamine with a valine (V600E), resulting in constitutively activation of the gene. In a study of BRAF V600E mutation in 24 ameloblastomas [14], 15 tumours (63\%) resulted positive for the mutation, without significant association with specific ethnicity, sex or age of the patients, or tumour histology. This mutation has been associated with resistance to EGFR-targeted drugs in primary ameloblastoma cells, similar to what happens in colorectal cancer.

HER2, also known as c-erb or HER2/neu, is a human epidermal growth factor receptor belonging to the same family of EGFR and its protein overexpression has been found in several carcinomas [19]. Previous studies showed that immunoreactivity for HER2 in ameloblastoma is significantly lower than in normal dental follicles $[15,19]$ and, albeit with some differences, all variants of ameloblastoma resulted negative or weakly positive for HER2. This is in agreement with the present case, which showed no immunohistochemical expression of HER2 protein, neither in the primary or metastatic lesions.

TP53 suppressor gene is situated on chromosome $17 \mathrm{p} 13$ and is one of the most frequently altered genes in tumours [20]. Mutation or loss of heterozygosity in the p53 gene or accumulation of its protein is associated with increased cellular proliferation 
and malignant transformation [21]. Ameloblastoma shows variable reactivity to p53 depending on the histological types, with plexiform variant being more frequently positive than follicular variant $[\underline{15}, \underline{20}]$. In our study, direct sequencing of TP53 did not show any alteration of the gene, while immunohistochemistry showed positive nuclear staining of neoplastic cells. This is in agreement with the results of the study by Kumamoto et al. [20], who observed no TP53 gene alteration in a series of 11 ameloblastomas, including a metastasizing example. However, these Authors found a higher expression of p53, MDM2 and p14 ${ }^{\mathrm{ARF}}$ in benign and malignant ameloblastomas than in tooth germs, supporting the hypothesis that these factors may be involved in the malignant transformation of odontogenic epithelium, while TP53 gene mutation is likely to play a minor role.

\section{CONCLUSIONS}

We report a case of ameloblastoma with metastatic spread to the brain and the neck after repeated local recurrences. Further studies are needed to identify molecular pathways that may provide an opportunity of alternative treatments and/or new potential predictive markers of local and distant spread of this rare tumour.

\section{ACKNOWLEDGMENTS AND DISCLOSURE STATEMENTS}

The authors report no conflicts of interest related to this study.

\section{REFERENCES}

1. Lin Y, He JF, Li ZY, Liu JH. Ameloblastoma with varied sites of metastasis: report of two cases and literature review. J Craniomaxillofac Surg. 2014 Jul;42(5):e301-4. [Medline: 24280106] [doi: 10.1016/j.jcms.2013.10.010]

2. Adebayo ET, Fomete B, Adekeye EO. Delayed soft tissue recurrence after treatment of ameloblastoma in a black African: case report and review of the literature. J Craniomaxillofac Surg. 2011 Dec;39(8):615-8. [Medline: 20584614] [doi: $10.1016 / \mathrm{j} . j \mathrm{jcms} .2010 .05 .010$ ]

3. Sciubba JJ, Eversole LR, Slootweg PJ. Odontogenic/ameloblastic carcinomas. In: Barnes L, Everson JW, Reichart PA, Sidransky D, editors. World Health Organization classification of tumors, Pathology and genetics of head and neck tumors. Lyon: IARC press. 2005. P. 287-9.

4. Houston G, Davenport W, Keaton W, Harris S. Malignant (metastatic) ameloblastoma: report of a case. J Oral Maxillofac Surg. 1993 Oct;51(10):1152-5; discussion 1156-7. [Medline: 8410456 ]

5. Berger AJ, Son J, Desai NK. Malignant ameloblastoma: concurrent presentation of primary and distant disease and review of the literature. J Oral Maxillofac Surg. 2012 Oct;70(10):2316-26. [Medline: 22281130] [doi: 10.1016/j.joms.2011.11.004]

6. Gilijamse M, Leemans CR, Winters HA, Schulten EA, van der Waal I. Metastasizing ameloblastoma. Int J Oral Maxillofac Surg. 2007 May;36(5):462-4. [Medline: 17275258] [doi: 10.1016/j.ijom.2006.12.005]

7. Dissanayake RK, Jayasooriya PR, Siriwardena DJ, Tilakaratne WM. Review of metastasizing (malignant) ameloblastoma (METAM): pattern of metastasis and treatment. Oral Surg Oral Med Oral Pathol Oral Radiol Endod. 2011 Jun;111(6): 734-41. [Medline: 21459020] [doi: 10.1016/j.tripleo.2010.12.018]

8. Praetorius F. Malignant odontogenic tumors. In: Barnes L, editors. Surgical pathology of the head and neck. New York: Informa Healtcare. 2009. p. 12902.

9. Van Dam SD, Unni KK, Keller EE. Metastasizing (malignant) ameloblastoma: review of a unique histopathologic entity and report of Mayo Clinic experience. J Oral Maxillofac Surg. 2010 Dec;68(12):2962-74. [Medline: 20970910] [doi: 10.1016/j.joms.2010.05.084]

10. Laughlin EH. Metastasizing ameloblastoma. Cancer. 1989 Aug 1;64(3):776-80. [Medline: 2663133] [doi: 10.1002/1097-0142(19890801)64:33.0.CO;2-8]

11. Vered M, Shohat I, Buchner A. Epidermal growth factor receptor expression in ameloblastoma. Oral Oncol. 2003 Feb;39(2):138-43. [Medline: 12509966] [doi: 10.1016/S1368-8375(02)00034-9]

12. Ueno S, Miyagawa T, Kaji R, Mushimoto K, Shirasu R. Immunohistochemical investigation of epidermal growth factor receptor expression in ameloblastomas. J Pathol. 1994 May;173(1):33-8. [Medline: 7931835]

13. Abdel-Aziz A, Amin MM. EGFR, CD10 and proliferation marker Ki67 expression in ameloblastoma: possible role in local recurrence. Diagn Pathol. 2012 Feb 2;7:14. [Medline: 22300665] [doi: 10.1186/1746-1596-7-14]

14. Kurppa KJ, Catón J, Morgan PR, Ristimäki A, Ruhin B, Kellokoski J, Elenius K, Heikinheimo K. High frequency of BRAF V600E mutations in ameloblastoma. J Pathol.2014 Apr;232(5):492-8. [Medline: 24374844] [PMC free article: 4255689] [doi: 10.1002/path.4317]

15. Jhamb T, Kramer JM. Molecular concepts in the pathogenesis of ameloblastoma: implications for therapeutics. Exp Mol Pathol. 2014 Dec;97(3):345-53. [Medline: 25194300] [doi: 10.1016/j.yexmp.2014.09.001] 
16. Catling AD, Schaeffer HJ, Reuter CW, Reddy GR, Weber MJ. A proline-rich sequence unique to MEK1 and MEK2 is required for raf binding and regulates MEK function. Mol Cell Biol. 1995 Oct;15(10):5214-25. [Medline: 7565670] [PMC free article: 230769] [doi: 10.1128/MCB.15.10.5214]

17. Moodie SA, Willumsen BM, Weber MJ, Wolfman A. Complexes of Ras.GTP with Raf-1 and mitogen-activated protein kinase kinase. Science. 1993 Jun 11;260(5114):1658-61. [Medline: 8503013] [doi: 10.1126/science.8503013]

18. Cantwell-Dorris ER, O'Leary JJ, Sheils OM. BRAFV600E: implications for carcinogenesis and molecular therapy. Mol Cancer Ther. 2011 Mar;10(3):385-94. [Medline: 21388974] [doi: 10.1158/1535-7163.MCT-10-0799]

19. Oikawa M, Miki Y, Shimizu Y, Kumamoto H. Assessment of protein expression and gene status of human epidermal growth factor receptor (HER) family molecules in ameloblastomas. J Oral Pathol Med. 2013 May;42(5):424-34. [Medline: 23278525] [doi: 10.1111/jop.12024]

20. Kumamoto H, Izutsu T, Ohki K, Takahashi N, Ooya K. p53 gene status and expression of p53, MDM2, and p14 proteins in ameloblastomas. J Oral Pathol Med. 2004 May;33(5):292-9. [Medline: 15078490] [doi: 10.1111/j.0904-2512.2004.00044.x]

21. Agarwal S, Mathur M, Srivastava A, Ralhan R. MDM2/p53 co-expression in oral premalignant and malignant lesions: potential prognostic implications. Oral Oncol. 1999 Mar;35(2):209-16. [Medline: 10435158] [doi: 10.1016/S1368-8375(98)00092-X]

\section{To cite this article:}

Rotellini M, Maggiore G, Trovati M, Saraceno MS, Franchi A.

Metastasizing Maxillary Ameloblastoma: Report of a Case with Molecular Characterization

J Oral Maxillofac Res 2016;7(1):e5

URL: http://www.ejomr.org/JOMR/archives/2016/1/e5/v7n1e5.pdf

doi: $10.5037 /$ jomr.2016.7105

Copyright (C) Rotellini M, Maggiore G, Trovati M, Saraceno MS, Franchi A. Published in the JOURNAL OF ORAL \& MAXILLOFACIAL RESEARCH (http://www.ejomr.org), 31 March 2016.

This is an open-access article, first published in the JOURNAL OF ORAL \& MAXILLOFACIAL RESEARCH, distributed under the terms of the Creative Commons Attribution-Noncommercial-No Derivative Works 3.0 Unported License, which permits unrestricted non-commercial use, distribution, and reproduction in any medium, provided the original work and is properly cited. The copyright, license information and link to the original publication on (http://www.ejomr.org) must be included. 